\title{
Losses and gains of soil organic carbon in grasslands in the Brazilian semi-arid region
}

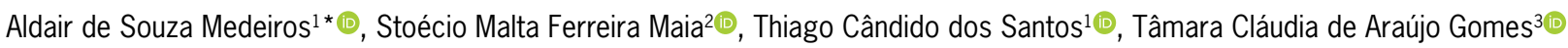

\author{
${ }^{1}$ Universidade Federal de Alagoas/Centro de Ciências \\ Agrárias, Rod. BR 104, km 85, s/n - 57100-000 - Rio \\ Largo, AL - Brasil. \\ Instituto Federal de Educação, Ciência e Tecnologia de \\ Alagoas, R. Lourival Alfredo, 176 - 57160-000 - Marechal \\ Deodoro, AL - Brasil. \\ ${ }^{3}$ Embrapa Tabuleiros Costeiros/Unidade de Execução de \\ Pesquisa e Desenvolvimento, Rod. BR 104, km 85, s/n - \\ 57100-000 - Rio Largo, AL - Brasil. \\ *Corresponding author <aldairmedeiros@gmail.com>
}

Edited by: Eduardo Alvarez Santos/Paulo Cesar Sentelhas

Received April 05, 2019

Accepted October 16, 2019

\begin{abstract}
Studies show that soil organic carbon (SOC) decreases between $3 \%$ and $9 \%$ in degraded grasslands in tropical regions, mainly due to the absence of techniques to enhance carbon contribution to soils. This study assessed SOC stock change factors for grassland management, specific to the semi-arid region of Brazil. These factors may contribute to a better understanding of SOC dynamics and could be used to improve inventories on GHG emissions. In addition, they could be used for updating default factors used by the Intergovernmental Panel on Climate Change. This study considers both soil sampling and a literature review, and comprises 27 paired comparisons, where the dataset was analyzed using a mixed linear model. For the grassland in the Brazilian semi-arid region, the SOC stock is reduced by between $12 \%$ and $27 \%$ due to inadequate management, overgrazing, and edaphoclimatic conditions of the Brazilian semiarid. However, this depends on aspects, such as land use and soil layer, which represents substantially more severe losses than in other regions of the country. We also found that losses occur during the first five years after conversion of native vegetation. The results also indicated a trend for SOC stocks to recover over time, reaching $4 \%$ after 30 years of use as grassland, probably related to the long period without soil tillage and the role of gramineas root system.

Keywords: Caatinga, soil organic matter, management factors, degraded grasslands
\end{abstract}

\section{Introduction}

The Brazilian cattle herd comprises roughly 172 million of animals and occupies an area of approximately 150 million hectares of grassland (IBGE, 2017). It is estimated that, overall, about $20 \%$ of these grasslands show some degree of degradation (Santana et al., 2019), and the main causes are related to inadequate management, especially the burning of native vegetation, low biomass production, and overgrazing, which exceeds the soil recovery capacity (FAO, 2017). In Brazil, absence of regular fertilization, incidence of pests and diseases, and progressive increase of invasive plants are other causes of grassland degradation (Sousa et al., 2012).

In the Brazilian semi-arid region, roughly 23.1 million hectares are used as grasslands (Santana et al., 2019), accounting for $26 \%$ of the region and $15 \%$ of grasslands in Brazil (Ribeiro et al., 2016). In addition to management issues, high temperatures and evapotranspiration, low and irregular rainfall in the region limit plant biomass production, which, among other factors, hinders stocks of soil organic carbon (SOC) in the semi-arid region (Oliveira et al., 2015).

Regarding changes in SOC stocks in grasslands, Ogle et al. (2004) estimated $3 \%$ losses in degraded grasslands and $17 \%$ increase in SOC stocks for improved grasslands in tropical regions using the meta-analysis with a global dataset. Similarly, Maia et al. (2009) found $9 \%$ reduction in degraded grasslands and $19 \%$ increase in improved grasslands in the Amazon and Cerrado regions of Brazil. These authors cite overgrazing and inadequate pasture management as the main factors for SOC losses.

The Intergovernmental Panel on Climate Change (IPCC) proposes the use of relative stock change factors for grassland management to assess soil $\mathrm{CO}_{2}$ emissions, due to changes in land use, based on national emission inventories and national removal inventories of greenhouse gases (GHG) (Eggleston et al., 2006). However, Brazil still has no specific SOC management factors for the semi-arid region. Therefore, this study assessed SOC stock change factors for grassland management (native and planted) specific to the semi-arid region of Brazil, which can privde a better understanding of SOC dynamics and could be used to improve national inventories on GHG emission and update default factors used by the IPCC.

\section{Materials and Methods}

\section{Study site}

The Brazilian semi-arid region covers approximately 1 million $\mathrm{km}^{2}$ (Althoff et al., 2018), in the northeastern region of Brazil and northern Minas Gerais (Figure 1), corresponding to $12 \%$ of the Brazilian territory (Lapola et al., 2014). The climate in the region is classified as hot and dry semi-arid. The average annual temperature ranges from $23{ }^{\circ} \mathrm{C}$ to $27{ }^{\circ} \mathrm{C}$, with relative humidity of $50 \%$ (Althoff et al., 2018).

In this region, rainfall ranges from 250 to 1000 $\mathrm{mm}$, and approximately $54 \%$ of the Brazilian semi-arid region has an average annual rainfall ranging from 500 to $750 \mathrm{~mm}$, while in $29 \%$, the range is from 750 to 1000 $\mathrm{mm}$, and only $17 \%$ of the region has an annual rainfall between 250 and $500 \mathrm{~mm}$ (Sampaio and Costa, 2011). In

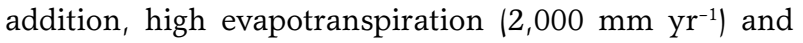
high temporal and spatial variations in rainfall, generally restricted to 2-4 months of the year (Maia et al., 2007), result in a negative water balance druing 7-11 months of the year in the Brazilian semi-arid region (Sampaio and Costa, 2011). 


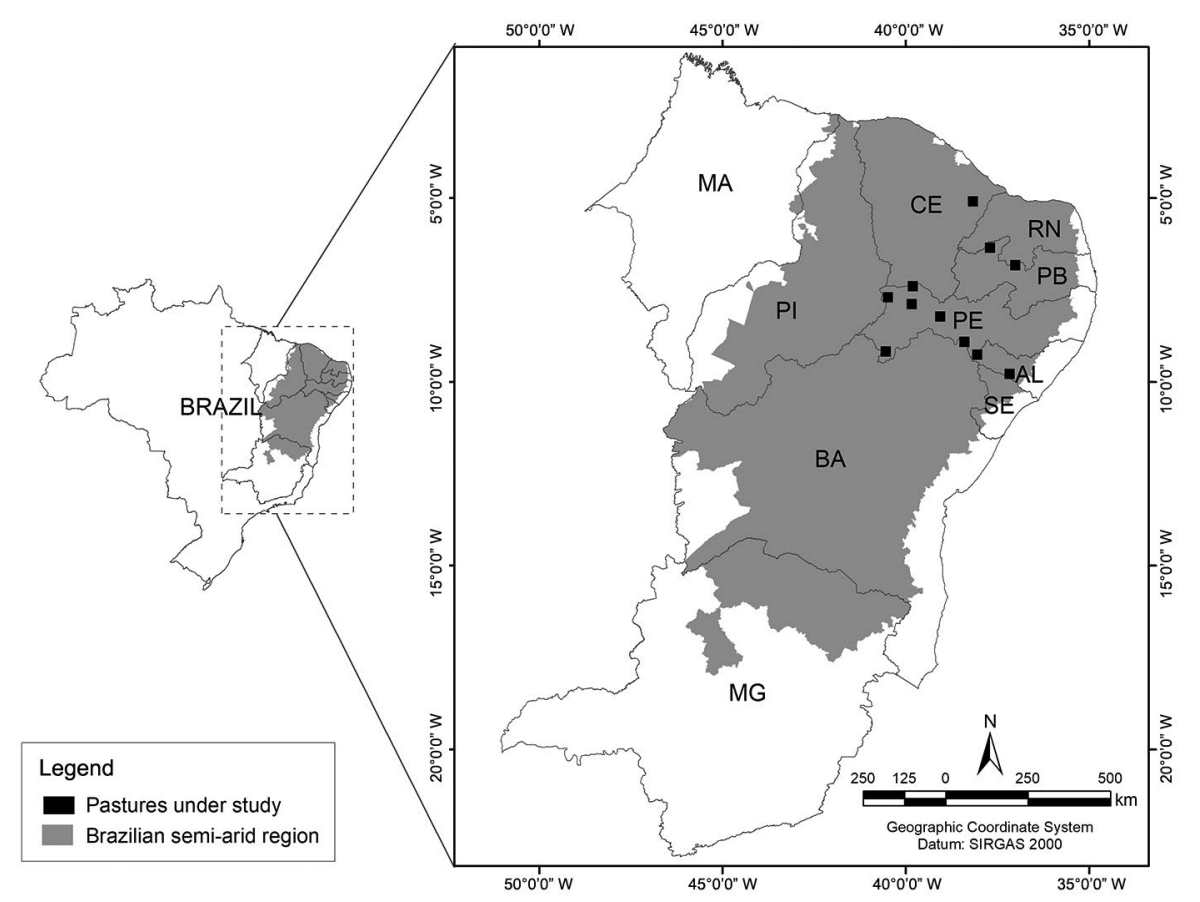

Figure 1 - Study sites to derive management factors for grasslands in the Brazilian semi-arid region.

The predominant soil types in the Brazilian semiarid region are Latosols (21 \%), Litholic Neosols (19 $\%)$, Argisols (15\%), Luvisols (13\%), Planosols (11\%), Quartzarenic Neosols (9 \%), Regolithic Neosolos (4 \%) and Cambisols (4\%), which altogether comprise $96 \%$ of the region (Giongo et al., 2011). Soil classification was performed based on the Brazilian system (Embrapa, 2006).

\section{Soil sampling}

This study assessed SOC stock change factors for grassland management in the Brazilian semi-arid region, and it was based on the combination of new soil carbon data with data from seven studies available in the literature (Table 1).

Soil samples were taken from areas of native vegetation known as "Caatinga" and native and planted (Digitaria decumbens) grassland in two municipalities in the semi-arid region of the states of Alagoas $109^{\circ} 55^{\prime}$ $\mathrm{S}, 37^{\circ} 03^{\prime} \mathrm{W}$, altitude of $\left.133 \mathrm{~m}\right)$ and Paraíba $\left(06^{\circ} 14^{\prime} \mathrm{S}\right.$, $37^{\circ} 41^{\prime} \mathrm{W}$, altitude of $\left.219 \mathrm{~m}\right)$. Two farms were randomly selected in each municipality for soil collection in paired observations, comparing SOC stocks between areas of grassland and native vegetation. Two criteria were used in the farm-selection process: (i) the owner or manager needed to be aware of land use and management practices adopted on the farm since conversion of native vegetation, and (ii) grassland areas should be close to native vegetation, with similar relief and comparable soil type and texture. In the pasture areas sampled, management began with deforestation and burning of native vegetation, followed by conventional soil tillage using plows, and without the adoption of good management practices, such as irrigation, liming, fertilizing or intercropping.

Soil samples were collected at three points for each site, which were selected randomly, however, always located in the same relief position for better spatial distribution within each chosen area, that is, native vegetation and grassland areas. Soil samples were collected up to $90 \mathrm{~cm}$ deep or until some limiting layer was found in the soils (Table 1 ) and in layers 0-10, 10-20, 20-30, 30-50, 50-70 and 70-90 cm.

\section{Calculation of SOC stock}

The samples were air dried and sieved through a 2-mm mesh to remove stones and fragments of branches and roots prior to analysis. The total soil carbon was measured by dry combustion in a Flash 2000 elemental analyser. Bulk density (BD) was measured by the volumetric ring method for each soil layer. SOC stock was calculated for each layer by multiplying $\mathrm{C}$ concentration $\left(\mathrm{g} \mathrm{kg}^{-1}\right)$ by $\mathrm{BD}\left(\mathrm{kg} \mathrm{cm}^{-3}\right)$ and the layer thickness $(\mathrm{cm})$. To calculate total SOC stock , the equivalent soil mass method (ESM) was adopted, following the procedure proposed by Sisti et al. (2004). Soil under native vegetation was used as a reference for the ESM method. Table 1 shows a summary of all the data used in this analysis.

\section{Literature review}

We carried out a literature review using the principal databases available (Scientific Electronic Library Online (SciELO), ScienceDirect, CAPES 


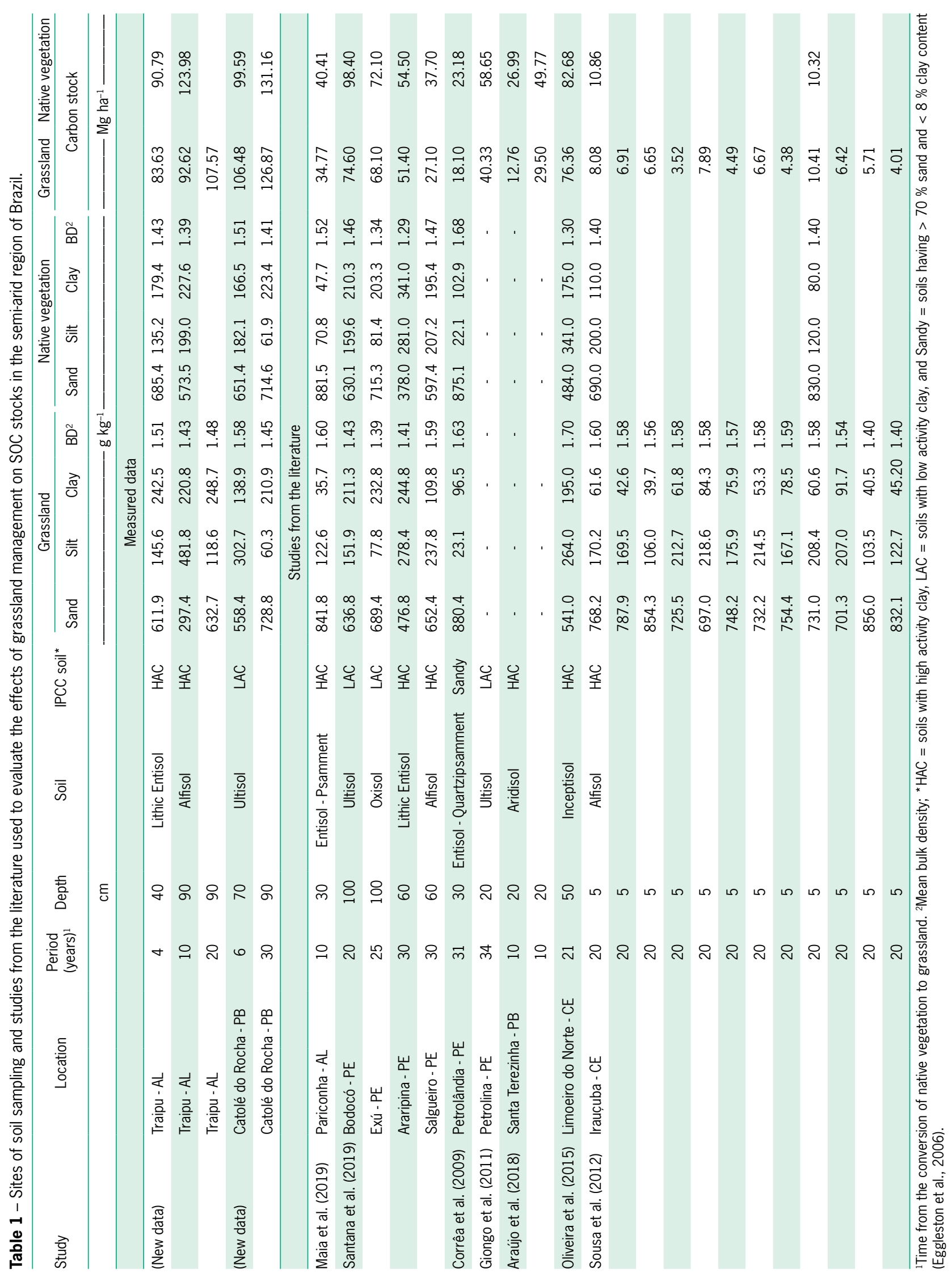


Newspaper Portal, Academic Google, Thesis and Dissertation Catalog) to assess the impact of managed grasslands on SOC stocks in the semi-arid region of Brazil (Figure 1). All the selected studies contained data on SOC stocks, or information that allowed calculation of this variable (bulk density, C content and depth of sampled layer), as wellas time since conversion of native vegetation to grassland. Literature data were also adjusted by the ESM method (Sisti et al., 2004).

We used seven studies of the literature (Table 1) in this research and added to the collected data, totaling 190 soil trenches. In each of these studies, changes in land use in the Brazilian semi-arid region occurred through deforestation and the burning of native vegetation, with soil conventional preparation using ploughs.

\section{Description of SOC stock change factors for grassland management and statistical analysis}

To assess SOC stock change factors for management of grasslands, the dataset (collected data and literature review) was analyzed using a mixed effect linear model, a regression analysis that includes fixed and random effects to describe the relationship between a response variable and the effects (fixed and random) (Pinheiro and Bates, 2000). The response variable for systems of managed grassland (Gs) corresponds to the average amount of SOC stored under management conditions modified by the average amount of SOC stored under native vegetation (NV) (i.e. SOC stock under Gs/SOC stock under NV).

We used fixed-effect variables to explain the influence of soil type, mineralogy, sample depth and time of land-use change. To include soil mineralogy, we used the classification proposed by the Eggleston et al. (2006) i) soils with high-activity clay (HAC), ii) soils with low-activity clay (LAC), and iii) soils with a content of less than $70 \%$ of sand and more than $8 \%$ of clay (sandy soils).

Random-effect variables were used to explain dependencies in multiple measurements within the same study (i.e. standard linear regression models assume that each observation is independent). Specifically, "municipalities" and "farms" were included as random variables. The variable "site" is common to all observations at the same farm (for different depth increments and sampling times); however, it is independent between different farms and, therefore, captures correlations between measurements from the same farm. Similarly, the variable "municipalities" is common to all observations from the same municipality, capturing correlations between observations from the same municipality (Pinheiro and Bates, 2000; Ogle et al., 2004; Maia et al., 2009, 2013).

The inclusion of different depths into the dataset followed the procedure proposed by Ogle et al. (2004). Two regressors $\left(\mathrm{X}_{1}\right.$ and $\left.\mathrm{X}_{2}\right)$ were formed from the upper and lower values of a soil-layer increment based on a quadratic function (assuming that the impact is larger on surface and decreases at depth in the profile). The average SOC stock ratio for a single increment was an integral from the upper to the lower depth of the quadratic function divided by increment thickness. The quadratic function was integrated using Equations (1) and (2):

$$
\begin{aligned}
& X_{1}=\frac{L^{2}-U^{2}}{2 \times(L-U)} \\
& X_{2}=\frac{L^{3}-U^{3}}{3 \times(L-U)}
\end{aligned}
$$

where: $L(\mathrm{~cm})$ represents the lower depth and $U(\mathrm{~cm})$ the upper depth. This approach allows to address measurements at various depths and develop models from the data without losing information on increment aggregation or interpolation for a standard set of depths.

The analyses allowed to derive management factors for the semi-arid region of Brazil consistent with the IPCC method for soil C (Eggleston et al., 2006), which is based on the integrated effect of management for $0-30 \mathrm{~cm}$ layer 20 years after a change in land-use or management system (Eggleston et al., 2006). However, factors were also derived for 0-50 and 0-100 cm layers, and for 5, 10, 15 and 30 years after a change in land use to grassland. Uncertainty was estimated by predicting the standard deviation of the value for each management factor.

\section{Results}

This study included the data collected, and seven other studies from the literature with data on SOC stock in native and planted grasslands (Table 1) for different layers (to a depth of $100 \mathrm{~cm}$ ), distributed over four states and 12 municipalities in the semi-arid region of northeastern Brazil (Figure 1), amounting to 27 paired comparisons.

In total, 15 management factors (Figure 2) were derived for the conversion of native vegetation to grassland, covering different periods ( 5 to 30 years) and soil depths $(0-30,0-50$ and $0-100 \mathrm{~cm})$. In $0-30 \mathrm{~cm}$ layer and for 20 years of use (default recommended by the IPCC), the management factor was $0.75 \pm 0.11$, which means a reduction of $25 \%$ in SOC stock. For the other periods $(5,10,15$ and 30 years $)$, the derived factors were $0.73 \pm 0.17,0.74 \pm 0.14,0.74 \pm 0.12$ and $0.77 \pm 0.13$, representing reductions in SOC stocks of $27 \%, 26 \%$, $26 \%$ and $23 \%$ respectively, when compared to SOC stocks of native vegetation. For $0-50 \mathrm{~cm}$ layer, factors of $0.81 \pm 0.19,0.82 \pm 0.16,0.83 \pm 0.14,0.83 \pm 0.13$ and $0.85 \pm 0.15$ were derived, which means losses of $19 \%$, $18 \%, 17 \%, 17 \%$ and $15 \%$; whereas for $0-100 \mathrm{~cm}$ layer, the derived factors were $0.84 \pm 0.20,0.85 \pm 0.18,0.86$ $\pm 0.16,0.86 \pm 0.16$ and $0.88 \pm 0.17$ (Figure 2), that is, conversion to grassland in the Brazilian semi-arid region reduced SOC stocks by $16 \%, 15 \%, 14 \%, 14 \%$ and 12 $\%$, when considering the soil layer down to $100 \mathrm{~cm}$ for periods of $5,10,15,20$ and 30 years respectively. 


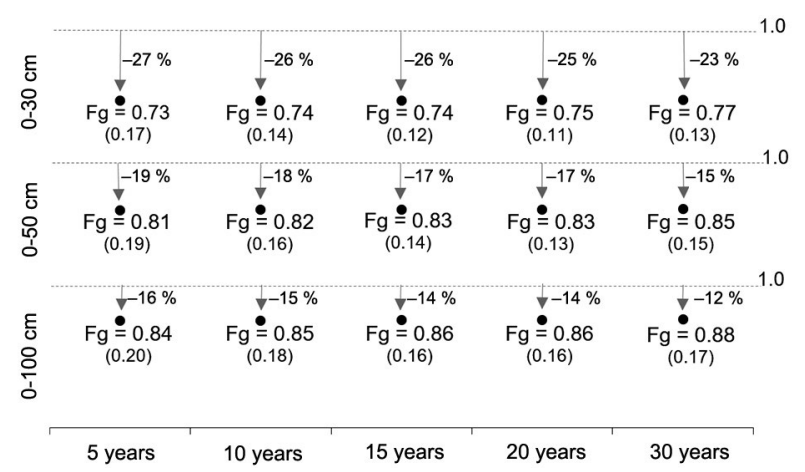

Figure 2 - SOC stocks change factors $( \pm 2$ standard deviation in parentheses) for managed grasslands ( $\mathrm{Fg}$ ) and derived for 5,10 , 15,20 and 30 years after conversion of the native vegetation to grassland, in the $0-30,0-50$ and $0-100 \mathrm{~cm}$ layers of soil in the semi-arid region in Brazil. The dashed line represents the baseline condition, meaning no change in grassland stocks regarding native vegetation.

Figure 3 shows the results for response variables, which represent the average rate of SOC stock for the soil under grassland systems/SOC stock under native vegetation for each paired comparison. The dataset was grouped considering the periods of land use $1 \leq 20$ and $>$ 20 years) and soil layers $(\leq 0-30$ and $>30 \mathrm{~cm})$. A response variable with a value equal to, less than or greater than 1 , indicates no change, or losses or gains in SOC stocks in the grassland system in relation to the native vegetation, respectively. The results showed greater SOC losses (33 $\%$ ) in the areas with $\leq 20$ years of land use, and response variables $<1$ were found in $90 \%$ of the dataset. In the areas with more than 20 years under grassland, all the data presented values $<1$; however, the average loss of SOC was $15 \%$, that is, substantially lower than that found in studies on grassland of less than 20 years usage. Soil depth showed the greatest C losses (39 \%) in the soil surface layers and response variables $<1$ were found in $94 \%$ of the dataset $\leq 30 \mathrm{~cm}$ of soil. However, at the deeper layers, SOC losses were also high, since for layers $>30 \mathrm{~cm}$, the average SOC loss was $11 \%$, and response variables with values of lower than 1 were found in $90 \%$ of the data (Figure 3).

\section{Discussion}

The results show that converting native vegetation (Caatinga) to native and planted grassland in the semiarid region of Brazil results in substantial SOC loss, which occurs during the first five years after land use change, since management factors showed a loss of $27 \%$ in SOC stock over the first five years, and then showed a recovery of SOC stock that reached $4 \%$ after 30 years of land use as grassland (Figure 2). Furthermore, average SOC loss (33\%) was significant in the dataset $\leq 20$ years, when compared to data from periods greater than 20 years $(15 \%)$. These results corroborate the recovery of
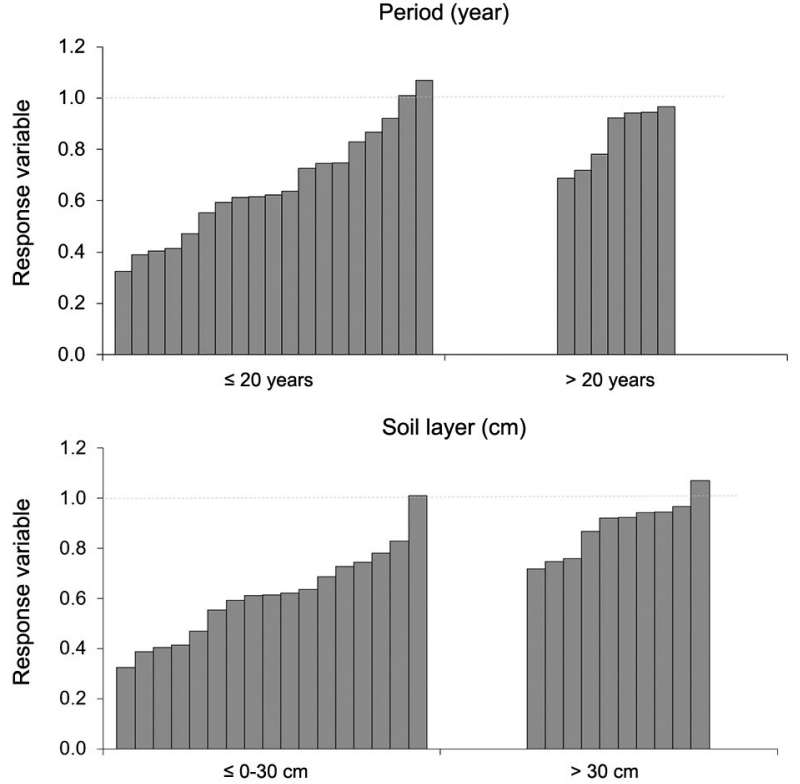

Figure 3 - Response variables between SOC stocks in grassland systems and native vegetation grouped by period of land use ( $\leq$ 20 and $>20$ years) and soil layer $(\leq 0-30$ and $>30 \mathrm{~cm})$ in the semi-arid region of Brazil.

SOC stocks over time, however, as observe in Figure 3, two observations from the dataset with up to 20 years of management showed response variables greater than 1 , indicating that even during the first years of management in moderately degraded grasslands, gains in SOC may occur in some situations.

This behavior is probably related to the way grassland is implemented and its subsequent management, in which deforestation and burning of the native vegetation is predominant, basically eliminating the litter entirely (Sampaio and Costa, 2011). The soil is then ploughed, consequently breaking soil aggregates, exposing SOM that was protected from the action of microorganisms. Even below-ground C stocks from native vegetation, which ranges from 3.43 to $8.50 \mathrm{Mg} \mathrm{ha}^{-1}$ depending on the physiognomy of the Caatinga (Santana et al., 2019) and the establishment of grasslands, are insufficient to offset SOC losses during the early years of management.

However, recovery of SOC stocks over time might be associated with lack of soil turning (Oliveira et al., 2015; Conant et al., 2017), input of organic material, greater root-system development of grasses, constant rhizodeposition, and more uniform distribution of root exudates in the soil (Oliveira et al., 2016; Segnini et al., 2019). The average $C$ stock below ground in grasslands of the Brazilian semi-arid region is approximately 2 $\mathrm{Mg} \mathrm{ha}^{-1}$ (Sampaio and Costa, 2011). These factors are possibly responsible for the recovery of SOC stocks in grasslands of the Brazilian semi-arid region over time. Further studies are necessary, however, to assess 
grasslands over longer periods to confirm this trend for SOC stocks to recover in the semi-arid region of Brazil.

The grasslands evaluated in this study are classified as moderately degraded and are grasslands with low productivity, cultivated without irrigation, fertilizers, or intercropping with legumes (Eggleston et al., 2006). For this grassland type, Maia et al. (2009) found an average SOC loss of $9 \%$ in the Amazon and Cerrado regions of Brazil, whereas Ogle et al. (2004), using a global dataset, pointed out losses of only $3 \%$ in SOC stocks in dry tropical regions, all of these results referring to $0-30 \mathrm{~cm}$ layer after 20 years of grassland. The results of Ogle et al. (2004) are used in the IPCC Guidelines for national GHG estimates (Eggleston et al., 2006). Specific evaluation of the results obtained in $0-30 \mathrm{~cm}$ layer after 20 years of grassland management in the Brazilian semi-arid region, $25 \%$ loss in SOC stocks is considerably greater than that found by Ogle et al. (2004) and Maia et al. (2009). Possibly, all this difference should be related to the aspects that control SOM dynamics and organic material input, such as climate (temperature, precipitation), pasture management (grazing intensity and biomass input), and soil (depth, texture, mineralogy, humidity) (Ogle et al., 2004; Maia et al., 2009; Sousa et al., 2012; Conant et al., 2017; Santana et al., 2019). Therefore, the results show the importance of more specific information on changes in SOC stocks for grasslands in semi-arid regions, since the differences found are significant and the more general results tended to underestimate SOC losses in these regions.

The greater SOC losses in grasslands of the Brazilian semi-arid region show that some aspects control this pattern, such as inadequate management practices and planting of grasslands in the region, which always takes place after deforestation and burning of native vegetation, followed by soil turning and management using low technological level, including failure to introduce more productive forage species to use irrigation and organic or inorganic fertilizers, and generally at stocking rates that exceed the support capacity of grasslands (Sousa et al., 2012; Schulz et al., 2016). According to Sousa et al. (2012), in northeastern Brazil, $74 \%$ of grasslands have a stocking rate (animal units/hectare) of less than 0.4 , which according to the authors, leads to the degradation of grasslands. According to Sampaio and Costa (2011), the prevailing management practice in grasslands of the Brazilian semi-arid region allows animals to consume as much plant biomass as possible due to a lack of forage and animal overcrowding, and leaving remaining biomass decompose during the dry season. In addition, plant biomass production in the semi-arid region is low (Althoff et al., 2018), due to poorly weathered soils, high temperatures, low and irregular rainfall, and high evapotranspiration (Giongo et al., 2011; Barros et al., 2015; Oliveira et al., 2015).

Xie and Wittig (2004) report that overgrazing leads to soil degradation and significant SOC loss, especially in regions with low precipitation and high evaporation, which impairs sustainability of grasslands in semi-arid regions (Fernandez et al., 2008; Abdalla et al., 2018). This is bescause overgrazing significantly reduces $\mathrm{C}$ uptake by grasses, including litter and roots (Wang et al., 2017). Furthermore, pressure from trampling by animals compacts surface layers, increasing bulk density and reducing infiltration and soil aeration (Xie and Wittig, 2004; Bernal et al., 2016). This limits development of the root system of the plants (Wu et al., 2014; Ribeiro et al., 2016; Schulz et al., 2016), with consequent reduction in SOC stocks, since leachate and root death are important to regulate SOC cycle in grasslands (Zhang et al., 2018).

These results are worrysome, since for the semiarid region of Brazil, future scenarios indicate that by 2100 , temperature of the region may increase from $0.6{ }^{\circ} \mathrm{C}$ to $5{ }^{\circ} \mathrm{C}$, and precipitation may decline by $10 \%$ to $20 \%$ (Marengo et al., 2009; Ribeiro et al., 2016). This could result in the substantial and progressive loss of SOC stocks in this region. In addition, the Brazilian semiarid region has recently experienced six consecutive years (2012-2017) of below-average rainfall.

Management factors also indicate that the impact of converting native vegetation to grassland in the Brazilian semi-arid region is not restricted to surface soil layers, since at 0-100 cm layer, SOC loss ranged between $12 \%$ and $16 \%$. Several physico-chemical processes provide high stability to SOC stored at deeper layers, which prevents its mineralization by microorganisms (Jobbágy and Jackson, 2000; Schmidt et al., 2011). However, the effects of environmental changes on SOC dynamics at depth have been little studied, since most research on SOC concentrates on the $0-50 \mathrm{~cm}$ layer of soil (Ogle et al., 2004; Numata et al., 2007; Corrêa et al., 2009; Maia et al., 2009; Giongo et al., 2011; Sousa et al., 2012; Oliveira et al., 2015; Maia et al., 2019).

SOC losses at depth in the Brazilian semi-arid region are probably related to some management practices, such as (i) lower input of forage biomass (Sampaio and Costa, 2011), since the input of plant residue and vertical distribution of roots throughout the profile affects SOC stocks at depth (Jobbágy and Jackson, 2000); (ii) increase in SOM mineralization rate (Carvalho et al., 2009), since the decomposition of organic residue determines $\mathrm{C}$ distribution at depth (Lim et al., 2018), and SOC is strongly associated to clay particles and minerals that act in stabilising and protecting SOM (Jobbágy and Jackson, 2000; Schmidt et al., 2011; Bertolin et al., 2016), (iii) a reduction in biomass input and compacting of layers through overgrazing (Ribeiro et al., 2016); and (iv) quality of organic residue, characterized by the lignin content, since organic residue from grassland has a lower lignin content in relation to native vegetation and is an important factor to control SOM decomposition rates, according to Jobbágy and Jackson (2000). These, therefore, are the main aspects that probably control SCO losses at deeper soil layers, when native vegetation is converted to grassland in the semi-arid region of Brazil. 


\section{Conclusion}

The results demonstrated that land use change from native vegetation to grassland (native and planted) in the semi-arid region of Brazil reduces SOC stocks from $12 \%$ to $27 \%$, depending on length of use and soil layer, which generally represents more severe losses than in other regions of the country. We also found that losses occur during the first five years after conversion of the native vegetation. However, the results indicate a trend for SOC stocks to recover over time, reaching $4 \%$ after 30 years under grassland. Studies are necessary in sites with longer periods of use as grassland to confirm these results. Furthermore, to avoid the SOC losses, it is recommended management techniques to increase the input of organic residue in grasslands of the semi-arid region of Brazil, during the first years after planting, for example, more productive forages, silvopastoral systems, irrigation, green fertilizer, and rotational grazing.

\section{Acknowledgements}

The authors would like to thank the Brazilian National Council for Scientific and Technological Development (CNPq) (CNPq - 446286/2015-0) for their financial support of this study and the Coordination for the Improvement of Higher Level Personnel (CAPES) for granting the post-graduate doctoral scholarship to A.S. Medeiros. We give thanks to all who offered their assistance during the field sampling and analyses, including the Technical Assistance and Rural Extension Company (EMATER) of the State of Alagoas, and the Department of Agriculture in the municipalities of Santana do Ipanema (Alagoas), Batalha (Alagoas), Santa Luzia (Paraíba) and Senhor do Bonfim (Bahia) for their support. Further thanks to the farm owners where soil samples were collected and the people who helped with the collection. Finally, to the Federal Institute of Education, Science and Technology of Alagoas, Marechal Deodoro (IFAL) and the Brazilian Agricultural Research Corporation (EMBRAPA) in Coastal Tablelands, for their support with the analyses.

\section{Authors' Contributions}

Conceptualization: Medeiros, A.S.; Maia, S.M.F. Data acquisition: Medeiros, A.S.; Maia, S.M.F.; Gomes, T.C.A. Data analysis: Medeiros, A.S.; Maia, S.M.F. Design of methodology: Medeiros, A.S.; Santos, T.C. Writing and editing: Medeiros, A.S.; Maia, S.M.F.

\section{References}

Abdalla, M.; Hastings, A.; Chadwick, D.R.; Jones, D.L.; Evans, C.D.; Jones, M.B.; Rees, R.M.; Smith, P. 2018. Critical review of the impacts of grazing intensity on soil organic carbon storage and other soil quality indicators in extensively managed grasslands. Agriculture, Ecosystems and Environment 253: 62-81.
Althoff, T.D.; Menezes, R.S.C.; Pinto, A.S.; Pareyn, F.G.C.; Carvalho, A.L.; Martins, J.C.R.; Carvalho, E.X.; Silva, A.S.A.; Dutra, E.D.; Sampaio, E.V.S.B. 2018. Adaptation of the century model to simulate $\mathrm{C}$ and $\mathrm{N}$ dynamics of Caatinga dry forest before and after deforestation. Agriculture, Ecosystems and Environment 254: 26-34.

Araújo, A.B.; Souto, P.C.; Souto, J.S.; Silva, F.J.A.; Leonardo, F.A.P.; Borges, C.H.A. 2018. Contribution of plant litter in fragments of dry tropical forest in Paraíba. Journal of Agricultural Science 10: 437-444.

Barros, J.D.S.; Chaves, L.H.G.; Pereira, W.E. 2015. Carbon and nitrogen stocks under different management systems in the Paraiban "Sertão". African Journal of Agricultural Research 10: 130-136.

Bernal, B.; McKinley, D.C.; Hungate, B.A.; White, P.M.; Mozdzer, T.J.; Megonigal, J.P. 2016. Limits to soil carbon stability: deep, ancient soil carbon decomposition stimulated by new labile organic inputs. Soil Biology \& Biochemistry 98: 85-94.

Bertolin, F.; Bono, J.A.M.; Macedo, M.C.M.; Araújo, A.R.; Pereira, F.A.R. 2016. Use and management of grassland in the Cerrado biome: impacts on aggregation of an oxisol. African Journal of Agricultural Research 11: 2139-2145.

Carvalho, J.L.N.; Cerri, C.E.P.; Feigl, B.J.; Píccolo, M.C.; Godinho, V.P.; Cerri, C.C. 2009. Carbon sequestration in agricultural soils in the Cerrado region of the Brazilian Amazon. Soil \& Tillage Research 103: 342-349.

Conant, R.T.; Cerri, C.E.P.; Osborne, B.B.; Paustian, K. 2017. Grassland management and conversion into grassland: effects on soil carbon. Ecological Applications 27: 662-668.

Corrêa, R.M.; Freire, M.B.G.S.; Ferreira, R.L.C.; Freire, F.J.; Pessoa, L.G.M.; Miranda, M.A.; Melo, D.V.M. 2009. Soil chemical properties under different uses in an irrigated area in the semiarid region of Pernambuco, Brazil. Revista Brasileira de Ciência do Solo 33: 305-314 (in Portuguese, with abstract in English).

Eggleston, S.; Buendia, L.; Miwa, K.; Ngara, T.; Tanabe, K. 2006. Guidelines for National Greenhouse Gas Inventories: Agriculture, Forestry and Other Land Use. IPCC, Hayama, Japan. v. 4.

Empresa Brasileira de Pesquisa Agropecuária [EMBRAPA]. 2006. Brazilian system of soil classification = Sistema Brasileiro de Classificação de Solos. 2ed. Centro Nacional de Pesquisa de Solos, Rio de Janeiro, RJ, Brazil (in Portuguese).

Fernandez, D.P.; Neff, J.C.; Reynolds, R.L. 2008. Biogeochemical and ecological impacts of livestock grazing in semi-arid southeastern Utah, USA. Journal of Arid Environments 72: 777-791.

Food and Agriculture Organization of the United Nations [FAO]. 2017. The State of Food and Agriculture. FAO, Rome, Italy. Available at: http://www.fao.org/3/a-I7658e.pdf [Accessed Feb 10, 2019]

Giongo, V.; Galvão, S.R.S.; Mendes, A.M.S.; Gava, C.A.T.; Cunha, T.J.F. 2011. Soil organic carbon in the Brazilian Semi-arid tropics. Dynamic Soil, Dynamic Plant 5: 12-20.

Instituto Brasileiro de Geografia e Estatística [IBGE]. Agricultural Census 2017. Preliminary Results = Censo Agropecuário 2017. Resultados Preliminares. IBGE, Rio de Janeiro, RJ, Brazil. Available at: https://biblioteca.ibge.gov.br/visualizacao/ periodicos/3093/agro_2017_resultados_preliminares.pdf [Accessed Feb 21, 2019] (in Portuguese). 
Jobbágy, E.G.; Jackson, R.B. 2000. The vertical distribution of soil organic carbon and its relation to climate and vegetation. Ecological Applications 10: 423-436.

Lapola, D.M.; Martinelli, L.A.; Peres, C.A.; Ometto, J.P.H.B.; Ferreira, M.E.; Nobre, C.A.; Aguiar, A.P.D.; Bustamante, M.M.C.; Cardoso, M.F.; Costa, M.H.; Joly, C.A.; Leite, C.C.; Moutinho, P.; Sampaio, G.; Strassburg, B.B.N.; Vieira, I.C.G. 2014. Pervasive transition of the Brazilian land-use system. Nature Climate Change 4: 27-35.

Lim, S.-S.; Baah-Acheamfour, M.; Choi, W.-J.; Arshad, M.A.; Fatemi, F.; Banerjee, S.; Carlyle, C.N.; Bork, E.W.; Park, H.-J.; Chang, S.X. 2018. Soil organic carbon stocks in three Canadian agroforestry systems: from surface organic to deeper mineral soils. Forest Ecology and Management 417: 103-109.

Maia, S.M.F.; Carvalho, J.L.N.; Cerri, C.E.P.; Lal, R.; Bernoux, M.; Galdos, M.V.; Cerri, C.C. 2013. Contrasting approaches for estimating soil carbon changes in Amazon and Cerrado biomes. Soil \& Tillage Research 133: 75-84.

Maia, S.M.F.; Gonzaga, G.B.M.; Silva, L.K.S.; Lyra, G.B.; Gomes, T.C.A. 2019. Soil organic carbon temperature sensitivity of different soil types and land use systems in the Brazilian semiarid region. Soil Use and Management 35: 433-442.

Maia, S.M.F.; Ogle, S.M.; Cerri, C.E.P.; Cerri, C.C. 2009. Effect of grassland management on soil carbon sequestration in Rondônia and Mato Grosso states, Brazil. Geoderma 149: 8491.

Maia, S.M.F.; Xavier, F.A.S.; Oliveira, T.S.; Mendonça, E.S.; Araújo Filho, J.A. 2007. Organic carbon pools in a Luvisol under agroforestry and conventional farming systems in the semi-arid region of Ceará, Brazil. Agroforestry Systems 71: 127-138.

Marengo, J.A.; Jones, R.; Alves, L.M.; Valverde, M.C. 2009. Future change of temperature and precipitation extremes in South America as derived from the PRECIS regional climate modeling system. International Journal of Climatology 29: 2241-2255.

Numata, I.; Chadwick, O.A.; Roberts, D.A.; Schimel, J.P.; Sampaio, F.F.; Leonidas, F.C.; Soares, J.V. 2007. Temporal nutrient variation in soil and vegetation of post-forest pastures as a function of soil order, pasture age, and management, Rondônia, Brazil. Agriculture, Ecosystems and Environment 118: $159-172$

Ogle, S.M.; Conant, R.T.; Paustian, K. 2004. Deriving grassland management factors for a carbon accounting method developed by the Intergovernmental Panel on Climate Change. Environmental Management 33: 474-484.

Oliveira, S.P.; Cândido, M.J.D.; Weber, O.B.; Xavier, F.A.S.; Escobar, M.E.O.; Oliveira, T.S. 2016. Conversion of forest into irrigated pasture. I. Changes in the chemical and biological properties of the soil. Catena 137: 508-516.

Oliveira, S.P.; Lacerda, N.B.; Blum, S.C.; Escobar, M.E.O.; Oliveira, T.S. 2015. Organic carbon and nitrogen stocks in soils of northeastern Brazil converted to irrigated agriculture. Land Degradation \& Development 26: 9-21.

Pinheiro, J.C.; Bates, D.M. 2000. Mixed-Effects Models in S and S-Plus. Springer, New York, NY, USA.
Ribeiro, K.; Sousa-Neto, E.R.; Carvalho Junior, J.A.; Lima, J.R.S.; Menezes, R.S.C.; Duarte-Neto, P.J.; Guerra, G.S.; Ometto, J.P.H.B. 2016. Land cover changes and greenhouse gas emissions in two different soil covers in the Brazilian Caatinga. Science of the Total Environment 571: 1048-1057.

Sampaio, E.V.S.B.; Costa, T.L. 2011. Stocks and fluxes of carbon in semiarid Northeast Brazil: preliminary estimates. Revista Brasileira de Geografia Física 6: 1275-1291 (in Portuguese, with abstract in English).

Santana, M.S.; Sampaio, E.V.S.B.; Giongo, V.; Menezes, R.S.C.; Jesus, K.N.; Albuquerque, E.R.G.M.; Nascimento, D.M.; Pareyn, F.G.C.; Cunha, T.J.F.; Sampaio, R.M.B.; Primo, D.C. 2019. Canbon and nitrogen stocks of soils under different land uses in Pernambuco state, Brazil. Geoderma Regional 15: e00205.

Schmidt, M.W.I.; Torn, M.S.; Abiven, S.; Dittmar, T.; Guggenberger, G.; Janssens, I.A.; Kleber, M.; Kögel-Knabner, I.; Lehmann, J.; Manning, D.A.C.; Nannipieri, P.; Rasse, D.P.; Weiner, S.; Trumbore, S.E. 2011. Persistence of soil organic matter as an ecosystem property. Nature 478: 49-56.

Schulz, K.; Voigt, K.; Beusch, C.; Almeida-Cortez, J.S.; Kowarik, I.; Walz, A.; Cierjacks, A. 2016. Grazing deteriorates the soil carbon stocks of Caatinga forest ecosystems in Brazil. Forest Ecology and Management 367: 62-70.

Segnini, A.; Xavier, A.A.P.; Otaviani-Junior, P.L.; Oliveira, P.P.A.; Pedroso, A.F.; Praes, M.F.F.M.; Rodrigues, P.H.M.; Milori, D.M.B.P. 2019. Soil carbon stock and humification in pastures under different levels of intensification in Brazil. Scientia Agricola 76: 33-40.

Sisti, C.P.J.; Santos, H.P.; Kohhann, R.; Alves, B.J.R.; Urquiaga, S.; Boddey, M.B. 2004. Change in carbon and nitrogen stocks in soil under 13 years of conventional or zero tillage in southern Brazil. Soil \& Tillage Research 76: 39-58.

Sousa, F.P.; Ferreira, T.O.; Mendonça, E.S.; Romero, R.E.; Oliveira, J.G.B. 2012. Carbon and nitrogen in degraded Brazilian semiarid soils undergoing desertification. Agriculture, Ecosystems and Environment 148: 11- 21.

Wang, Y.; Heberling, G.; Gorzen, E.; Miehe, G.; Elke, S.; Karsten, W. 2017. Combined effects of livestock grazing and abiotic environment on vegetation and soils of grasslands across Tibet. Applied Vegetation Science 20: 327-339.

Wu, X.; Li, Z.; Fu, B.; Zhou, W.; Liu, H.; Liu, G. 2014. Restoration of ecosystem carbon and nitrogen storage and microbial biomass after grazing exclusion in semi-arid grasslands of Inner Mongolia. Ecological Engineering 73: 395-403.

Xie, Y.; Wittig, R. 2004. The impact of grazing intensity on soil characteristics of Stipa grandis and Stipa bungeana steppe in northern China (autonomous region of Ningxia). Acta Oecologica 25: 197-204.

Zhang, M.; Li, X.; Wang, H.; Huang, Q. 2018. Comprehensive analysis of grazing intensity impacts soil organic carbon: a case study in typical steppe of Inner Mongolia, China. Applied Soil Ecology 129: 1-12. 